\title{
De trajetórias que fizeram uma sura do Corāo a repensar as origens do islā
}

\section{On the Trajectories that Made a Certain Qur'anic Sura Rethink the Origins of Islam}

\author{
Pedro Lima Vasconcellos ${ }^{1}$ \\ Universidade Federal de Alagoas (Brasil)
}

Recibido: 30-01-19

Aprobado: 18-02-19

\section{Resumo}

O artigo parte de uma aproximação à sura 19 para problematizar a forma convencional de se compreenderem a formação do Corão e as origens do islã. Por uma análise rápida dos materiais e das fontes que mostram o texto mostra como as teorias tradicionais sobre o surgimento de ambos são inadequadas porque não consideram a dinâmica e a vitalidade da cultura, bem como o complexo quadro das tradições religiosas presentes no Oriente Médio dos tempos da Antiguidade tardia, especialmente aquelas que de alguma forma poderiam ser nomeadas judias ou cristãs. E propõe que do interior daquilo que se costuma chamar judeu-cristianismo emergem tanto um (o Corão) quanto outro (o islã em seus primórdios).

Palavras-chave: Sura 19, Corão, islã dos primórdios, judeu-cristianismo, Antiguidade tardia

\begin{abstract}
The article comes from an approach to the Surah 19 to enquire the conventional way to comprehend the formation of Qur'ān and the origins of

\footnotetext{
${ }^{1}$ (plvascon@uol.com.br) Mestre e livre-docente em Ciências da Religião, doutor em Ciências Sociais, pós-doutor em História e professor do programa de pós-graduação em História, da Universidade Federal de Alagoas (UFAL). Sobre o tema Antonio Conselheiro e Belo Monte, publicou os seguintes livros: Do Belo Monte das Promessas à Canudos Destruída: o Drama Bíblico da Jerusalém do Sertão (Catavento, Maceió, 2010), Missão de Guerra: Capuchinhos no Belo Monte de Antonio Conselheiro (Edufal, Maceió, 2014) e O Belo Monte de Antonio Conselheiro: uma Invenção "Biblada" (Edufal, Maceió, 2015).
} 
Islam. From a short analysis of materials and sources that appear on the text, it is possible to see how traditional theories about the emergence of both are inadequates because do not consider the dynamic and vitality of the culture, as well the complexity of religious traditions forceful in the Middle East during the Late Antiquity, especially those which could be appointed as Jewish or Christian. And it argues that from the interior of what is commonly called Jewish-Christianism emerge both one (the Qur'ān) and the other (the Early Islam).

Key-words: Surah 19 - Qur'ān - Early Islam - Jewish Christianity - Late Antiquity.

O presente texto pouco tratará do islã naquela configuração mais definida, que não pode ser identificada senão no século VIII já bem avançado, mas ao mesmo tempo latente já em tempos muito anteriores, inclusive àqueles supostos para seu mítico iniciador, Muhammad. Mas tratará muito dos entornos e dos ambientes que o fizeram e viram nascer. Não proporá um traçado linear que conduziria a ele; diferentemente disso, apresentará algumas cenas ou situações capazes de fazer compreender como o islã não emerge como um corpo estranho ou de forma repentina. Não é um ente alienígena no Oriente Médio dos tempos da Antiguidade tardia; pelo contrário, aparece como uma, entre tantas consolidações que seriam possíveis, que reúne feixes de tradições e culturas de larga duração e circulação naquelas paragens e épocas. Como a emergência do Islã e a confecção do Corão aparecem como processos inevitavelmente imbricados, ao tratar de um inevitavelmente serei remetido ao outro; o recurso a uma passagem do livro - aquela que hoje se apresenta como a primeira metade de sua sura 19, servirá para ilustrar o caminho reflexivo que aqui proponho. Os elementos que a pesquisa mais recente tem permitido descortinar sobre o que terão sido os materiais constitutivos dela indicarão possibilidades de se repensarem as origens do islã no quadro tumultuado, complexo e empolgante do Oriente Médio nos últimos séculos da Antiguidade.

\section{De um fragmento corânico a trajetórias de muitos sujeitos}

\subsection{Um viajante e uma récita}

Imaginemos alguma paragem do antigo Oriente Próximo (quem sabe a Arábia; mas bem poderia ser algum lugar da Síria, da Palestina, ou mesmo da Pérsia), na virada para o século VIII de nossa era. E nela alguém bem-informado, sabedor do que ocorria nas imediações, particularmente as tensões que sacudiam 
as relações entre bizantinos e sassânidas, ou as invasões sofridas por Jerusalém, que naqueles tempos - e já fazia séculos - era conhecida com o nome latino de Aelia (nas fontes árabes, Iîliyâ'). Alguém consciente também das oposições intensas entre grupos que diziam representar o verdadeiro cristianismo, sendo ele, seguramente, adepto de uma dessas correntes. Viajado que era (conhecia praticamente todas as principais rotas que aproximavam cidades tão distantes como Constantinopla e Meca, Alexandria e Persépolis, passando por Damasco, Yatrib e Antioquia), seria também conhecedor do amplo espectro religioso que caracteriza a região. Um escriba, quem sabe, leitor ávido e ouvinte atento das histórias sobre Jesus que circulavam por meio de inúmeros textos e em animadas rodas de discussão, às vezes mais acesas, percebia que os diversos relatos, lidos ou proclamados, estavam longe de ser concordes em detalhes significativos, e não poucas vezes davam margem a interpretações divergentes. Seria também dado a peregrinações: conhecia de perto os lugares santos da Palestina. Ainda mais: sabedor de algumas das línguas e dialetos ancestrais falados nessas tantas paragens, distinguia entre distintas formas litúrgicas adotadas aqui e ali nesse amplo e diversificado ambiente. E finalmente, para não me alongar em demasia sobre os tantos predicados admiravelmente reunidos numa única pessoa: cristã ${ }^{2}$ que era, conhecia em minúcias os textos sagrados de tantos segmentos que, duma forma ou de outra, se entendiam vinculados ao pai Abraão, e dominava o repertório das peripécias e sagas que se contavam dele, mas também de Noé, Moisés, Davi, os diversos profetas, etc. Pois bem, imaginemo-lo em alguma dessas paragens, ingressando num lugar de reunião em que suas crenças, assim esperava, se veriam de alguma forma reiteradas no rito que ali deveria ocorrer, relacionado ao Natal de Jesus. Em seu desenrolar terá escutado - possivelmente em árabe, mas bem poderia ser em siríaco - uma proclamação cujos contornos seriam basicamente os seguintes ${ }^{3}$ :

${ }^{1}$ Caf, Ha, Yá, Ain, Sad.

${ }^{2}$ Lembrança da misericórdia de teu Senhor para com o seu servo, Zacarias.

${ }^{3}$ Quando ele chamou seu Senhor, em chamado secreto, ${ }^{4}$ ele disse: "Meu Senhor, os meus ossos estão debilitados, minha cabeça com cabelos brancos arde; mas não tenho desanimado em minhas súplicas a ti, meu Senhor! ${ }^{5}$ Em verdade, temo

${ }^{2} \mathrm{O}$ uso deste termo neste ensaio pareceria óbvio. Mas ele comporta uma série de riscos, que resumo o problema em duas ponderações: a) como será visto no decorrer destas páginas, o termo estava longe, naqueles tempos de nosso viajante, de indicar uma única identidade, de contornos nítidos e indiscutíveis; pelo contrário, por cristãos se entendiam indivíduos e contingentes com crenças e práticas virtualmente distintas e mesmo opostas entre si; b) no contexto que aqui interessa cristianismo era algo cuja identidade não só se debatia entre os grupos que reivindicavam o nome, mas com relação a outras identidades em busca de definição formal: o judaísmo e o próprio islã. É preciso não projetar anacronicamente rupturas posteriores para tempos ancestrais: as linhas fronteiriças estavam muito pouco identificadas ou definidas.

3 Apresento o texto tal como costuma aparecer nas edições modernas do Corão, com a numeração das aleias ("a.": versículos); interrompo a sequência para inserir comentários, destacando elementos da articulação deste fragmento textual. Para a tradução dele foram particularmente importantes o ensaio de Toorawa (2011) e as notas encontradas em Nasr 2015: 763-774. 
os sucessores, depois de mim, visto que minha mulher é estéril. Então dá-me, de tua parte, um herdeiro, ' ${ }^{6}$ ue herdará de mim e herdará da família de Jacó. E faze-o, meu Senhor, agradável!” "“Ó Zacarias, na verdade te alvissaramos sobre um menino, de nome João. Não fizemos tal nome a ninguém, antes". ${ }^{8}$ Ele disse: "Meu Senhor, como posso ter um menino, se minha mulher é estéril e eu cheguei à idade extrema?" "Ele disse: "Assim disse teu Senhor: "Isso me é fácil; eu te criei antes, embora não fosses algo"”. ${ }^{10} E l e$ disse: "Meu Senhor, faze-me um sinal!" Ele disse: "Teu sinal será: não falarás ao povo durante três noites, [mesmo estando] perfeito". ${ }^{11}$ Então ele voltou do santuário ao povo; então indicou-lhes que glorificassem, de manhã e à tarde.

12“'Oh, João, toma o livro com determinação!" E lhe concedemos a sabedoria ainda criança, ${ }^{13} \mathrm{e}$ afeição de nossa parte, como com as nossas clemência e piedade, e foi correto, ${ }^{14} \mathrm{e}$ atencioso para com seus pais, e jamais foi arrogante, rebelde.

${ }^{15} \mathrm{~A}$ paz com ele no dia em que nasceu, no dia em que morra e no dia em que for levantado, vivo.

Depois da enunciação de cinco letras do alfabeto árabe (na a.1), algo que nos soa misterioso e enigmático ${ }^{4}$, temos uma fórmula de introdução (a.2), pela qual se apresenta o diálogo (da divindade?) com Zacarias, por meio do qual se anuncia o nascimento de João (a.3-11); à prece do ancião (a.3-6) se responde com uma promessa divina e sinais (a.7-11). Logo depois se sumariza o que terá sido o sentido básico da vida deste, abençoado divinamente (a.12-14). Ao final (a.15) uma fórmula, que reencontrará quase idêntica, logo adiante. A nosso ouvinte tudo isso parecia estranhamente familiar; mas ainda mais intrigante foi, continuando a audição, deparar-se com o que a narração ainda lhe reservava:

\begin{abstract}
${ }^{16} \mathrm{E}$ lembra Maria, no Livro,
que se retirou de sua família, rumo a um lugar ao oriente. ${ }^{17}$ Então tomou deles um véu. Então lhe enviamos nosso espírito, que lhe apareceu como um homem perfeito. ${ }^{18}$ Ela disse: "Guardo-me de ti no Misericordioso, se és correto". ${ }^{19} \mathrm{Ele}$ disse: "Sou apenas mensageiro de teu Senhor, para que eu te dê um menino puro". ${ }^{20}$ Ela disse: "Como posso ter um menino, se nenhum homem me tocou e não sou depravada?" ${ }^{21}$ Ele disse: "Assim disse teu Senhor: 'Isso Me é fácil! E faremos disso um sinal para o povo, e misericórdia da Nossa parte'. E foi uma ordem decretada". ${ }^{22}$ Então ela o concebeu; e retirou-se com ele a um lugar afastado.

${ }^{23}$ Então a conduziram as dores do parto ao tronco de uma palmeira. Ela disse: "Oh, eu desejaria ter morrido antes disto, estaria no esquecimento, esquecida". ${ }^{24}$ Então, chamou [uma voz], de debaixo dela: "Não te atormentes, porque fez correr teu Senhor debaixo de ti um regato! ${ }^{25} \mathrm{E}$ sacode na tua direção o tronco da palmeira; cairão sobre ti frutos maduros, frescos. ${ }^{26}$ Então come e bebe, e refresca os olhos. Então, se vires algum dos mortais, então dize: "Fiz um voto
\end{abstract}

\footnotetext{
${ }^{4}$ Quanto ao significado do que na pesquisa é denominado "letras enigmáticas" ou "misteriosas" do Corão, algo que acontece no início desta e de mais outras vinte e oito suras que o compõem, poder-seia tratar-se de abreviações de fórmulas litúrgicas cristãs siríacas (Dye 2012: 62, n.18).
} 
ao Misericordioso, então não falarei hoje ao povo".

${ }^{27}$ Então veio com ele a seu povo, trazendo-o. Disseram: "Ó Maria, certamente conduziste algo grave! ${ }^{28}$ Ó irmã de Aarão, teu pai não foi um homem do mal, nem tua mãe uma depravada!" ${ }^{29}$ Então ela apontou para ele. Disseram: "Como

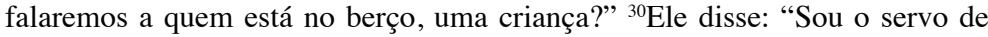
Deus, o qual me concedeu o livro e me fez profeta. ${ }^{31} \mathrm{E}$ me fez abençoado, onde quer que eu esteja, e me encomendou a oração e a esmola enquanto eu esteja vivo. ${ }^{32} \mathrm{E}$ [me fez] atencioso para com a minha mãe, e não me fez arrogante, desanimado.

${ }^{33} \mathrm{E}$ a paz sobre mim, no dia em que nasci, no dia em que eu morra e no dia em que eu for levantado, vivo".

Como se vê, a sequência do texto se constitui noutra sessão, agora focada na figura de Maria (indicado já na introdução: a.16a), e nas circunstâncias em que ela gera e dá à luz seu filho, mais à frente identificado por seu nome, Jesus. Também aqui o esquema parece claro, embora um tanto mais complexo. A marca é fundamentalmente narrativa; são três os momentos focados, e em cada um deles os diálogos são decisivos: 1) o anúncio a Maria, por um mensageiro divino, do nascimento de um filho (a.16b-22); 2) o parto da criança, em condições dramáticas (a.23-26); 3) questionamentos à mãe e manifestação da criança indicando o rumo que sua vida, também abençoada, haverá de ter (a.2733).

Estes dois relatos (o primeiro centrado em Zacarias, o segundo em Maria) têm elementos internos a aproximá-los, e assim deixá-los efetivamente coesos num todo textual: a) ambos se iniciam com o apelo à "lembrança"; b) a primeira reação de ambos ao anúncio divino se expressa praticamente da mesma forma, assim como a resposta divina a ela; c) o modo como ambos os relatos terminam (uma fala sobre João e uma auto-apresentação de Jesus). E no tocante a cada um dos infantes, para além das características próprias a cada um deles, ainda se destacam: a) a referência a um "livro", cuja observância é pedida a um e cuja entrega é garantida ao outro; b) a ambos são atribuídas virtudes, particularmente a atenção (para com os pais, no caso de João; para com a mãe, no caso de Jesus) e a ausência de arrogância e rebeldia/desânimo; c) principalmente o que denominei "fórmula conclusiva" soa como um refrão (não fora a mudança da terceira para a primeira pessoa do singular) a concluir os dois relatos, na referência à paz presente no nascimento, no dia da morte e naquele da ressurreição de João e de Jesus.

Ao final, os dois quadros, claramente delimitados, chamam a atenção tanto por seu acentuado paralelismo como pelas características próprias a cada qual que se evidenciam quando eles são confrontados ${ }^{5}$ :

\footnotetext{
${ }^{5}$ O quadro a seguir retoma e revê, em alguns detalhes, aquele de Aisha Geissinger (2009: 383).
} 


\begin{tabular}{|c|c|}
\hline $\begin{array}{l}\text { Zacarias/João } \\
\text { Introdução (a.2) } \\
\text { Prece em segredo por um herdeiro (a.3- } \\
\text { 6) } \\
\text { Anúncio de nascimento (a.7) } \\
\text { Dúvidas (a.8-9) } \\
\text { Pedido de sinal (a.10) } \\
\text { Exortação ao povo por gestos (a.11) } \\
\text { Descrição de João (a.12-15) }\end{array}$ & $\begin{array}{l}\text { Maria/Jesus } \\
\text { Introdução (a.16a) } \\
\text { Afastamento da família (a.16b) } \\
\text { Anúncio de nascimento (a.17-19) } \\
\text { Dúvidas (a.20) } \\
\text { Garantia de sinal (a.21) } \\
\text { Concepção e isolamento (a.22) } \\
\text { Parto (a.23) } \\
\text { Voz e indicações (a.24-26) } \\
\text { Reprovação por sua gente (a.27-28) } \\
\text { Resposta por gestos (a.29) } \\
\text { Auto-descrição de Jesus (a.30-33) }\end{array}$ \\
\hline
\end{tabular}

E a essa altura de sua escuta o peregrino deve ter recordado textos num formato comum a este que agora estava a conhecer, numa forma literária típica de um universo com o qual ele estava bem familiarizado, o das igrejas siríacas: a chamada soghitha, isto é, um poema feito de estrofes e refrões, bem como da alternância entre narração e diálogo, que põe em cena figuras bíblicas. E não terá deixado de notar, ainda, que o paralelo entre os dois quadros acentua um contraste referente à significação dos recém-nascidos para o pai do primeiro e para a mãe do segundo: se para Zacarias o filho é uma dádiva que atende a seu anseio mais secreto, para Maria a concepção e o parto de Jesus são causa, em absoluta solidão, de dramático e prolongado constrangimento - que o texto nem de longe pretende disfarçar - pelas circunstâncias em que ocorrem, algo que deverá esperar a intervenção miraculosa do bebê para se ver dissipado. Nada de alvíssaras, como na a.7. E isto não é pouca coisa, muito menos pode ser ignorado ou negligenciado em nome do evidente paralelo entre os dois momentos da narração aqui considerados (Geissinger 2009: 384-385).

A partir da a.34 há um deslocamento importante, seguramente percebido por nosso arguto ouvinte: o que ora vem faz as vezes de comentário a respeito do menino que, na cena anterior, no colo de sua mãe acaba de fazer algo como uma "apresentação de si mesmo". Não se introduzem novas personagens, novas cenas, novos diálogos: sai-se da narração, do âmbito do mito e se entra, de cheio, no terreno da história e da polêmica ${ }^{6}$, ao que parece em dois momentos: um especificamente focado nas discussões a respeito da identidade de Jesus em sua relação com Deus (a.34-37); outro com acento escatológico, remetendo

\footnotetext{
${ }^{6}$ Segundo Dye (2012: 63), esta sessão polêmica, ao romper a coerência do conjunto que vai até a a.63, o equilíbrio entre as partes que o compõem e a continuidade das rimas, mostraria ser uma interpolação posterior, de toda forma realizada antes do fim do século VII. Para meus propósitos essa questão não importa, ao menos nesse momento; nosso fictício ouvinte, e guia pelos meandros do mundo em que e de que nascia a sura 19, a conhece já com esta presumível inserção.
} 
ao evento do juízo final (a.38-40). O giro, do ponto de vista do estilo e do conteúdo, se manifesta claramente:

\begin{abstract}
${ }^{34}$ Este é Jesus, filho de Maria; um dito de verdade, da qual duvidam. ${ }^{75}$ É inadmissível que Deus tenha tomado um filho. Glória a ele! Quando decreta uma ordem, então apenas diz: "Seja!", e é. ${ }^{36 “ " E ~ e i s ~ q u e ~ D e u s ~ e ́ ~ m e u ~ S e n h o r ~}$ e vosso Senhor. Então adorai-o! Este é o caminho reto". ${ }^{87}$ Então as seitas divergiram entre elas. Então ai daqueles que descreem quanto a testemunhar o grande dia! ${ }^{38}$ Como ouvirão e verão, no dia em que vierem a nós! Porém, os malfeitores [estão], hoje, em evidente erro. ${ }^{39} \mathrm{E}$ admoesta-os sobre o dia do lamento, quando a ordem tiver sido decretada. E eles estão em agitação e não creem. ${ }^{40} \mathrm{Em}$ verdade, nós herdaremos a terra e quem está nela, e a nós eles serão retornados.
\end{abstract}

Não há como escapar: o que tal viajante acabava de ouvir lhe soava absolutamente familiar, em tantos detalhes. Eram muitas reminiscências, leituras e audições, lugares santos visitados, rituais e símbolos vários com os quais tomara contato. Mas a configuração do conjunto textual lhe soou inédita; seus contornos the pareceram novos, e ela não terá deixado de experimentar algum atordoamento e estranheza, particularmente com a concisão que o caracteriza. ${ }^{9}$

Mas de uma coisa este anônimo polivalente não estava ciente: ele acabara de ouvir a proclamação de um texto que estava em vias de compor a escritura sagrada de um sistema religioso que àquele momento caminhava para acentuar alguns de seus primeiros e ainda vagos contornos. Nos dias atuais só conhecemos esse teor como constitutivo do Corão muçulmano, mas a nosso personagem não era possível o entendimento antecipado dos rumos daquilo que, efetivamente, se desenvolvia diante de seus olhos. Assim, interessa aqui recuperar o que podem ter sido lembranças e associações de este bem-informado "cristão" do mundo médio-oriental em torno do ano 700 de nossa era, bem como as raízes de tantas reminiscências que teriam vindo à tona quando da visita deste viajante, peregrino daquelas terras, sabedor de tantas narrativas, leitor de muitos livros. Ou seja, para quais paragens do passado e do presente tais lembranças o terão remetido. Foram muitas.

\footnotetext{
${ }^{7}$ Há quem proponha traduzir "sobre quem eles disputam" ou "sobre o que eles falam em excesso".

${ }^{8}$ Entendo a a.36 como discurso direto em que o próprio Jesus fala (Robinson 2003: 235-236.238).

9 Foge aos escopos deste trabalho a análise de como este conjunto textual, elaborado no manejo de tantos dados, fontes e informações, não é um pastiche em que os elementos apareceriam dispostos em desordem; pelo contrário, o todo soa fortemente articulado, e é inegável o talento literário de quem deu a forma final à passagem, em vistas a intencionalidades específicas que presidiram sua confecção. 


\subsection{Trajetórias}

A nós, vivendo quase um milênio e meio depois, a identificação destes cenários soa desafiadora. Mas a pesquisa tem mostrado muita coisa a este respeito, mesmo que tanto ainda permaneça desconhecido. Vamos a alguns dos resultados por ela trazidos.

Terão sido, mesmo, muitas as lembranças evocadas naquela inusitada oportunidade experimentado por nosso viajante. E se lhe pedíssemos a que, do alto de sua calejada trajetória, iluminada de tantas memórias, oferecesse uma primeira síntese dos impactos que o fragmento ouvido lhe produziu, que ao mesmo tempo desse conta do percurso feito e identificasse questões a serem retomadas e trabalhadas mais alongadamente, creio que o resultado seria algo semelhante ao que exponho nas linhas a seguir. A constatação geral é a de que praticamente nenhum elemento ou detalhe encontrado no fragmento aqui considerado deixa de ecoar antigos textos, lugares venerados, debates de longa duração, crenças tão ardorosamente professadas como contestadas no universo "cristão" médio-oriental daqueles tempos; senão vejamos:

a) a estrutura geral do texto, baseada na sequência Zacarias/João-Maria/ Jesus, repousa num eixo que remete ao evangelho segundo Lucas, com ou sem a mediação do Diatessaron de Taciano; este embasamento pode ser verificado nos detalhes, nas suposições, omissões, adições e correções que o texto parece estabelecer sobre esta tradição;

b) em sua elaboração o texto ecoa elementos importantes encontrados em livros, narrativas e/ou discursos que tinham presença significativa naquela época e ambiente de fala-escrita majoritariamente siríaca, embora sejam pouco conhecidos na atualidade; refiro-me às tradições sobre o nascimento de Jesus encontradas em textos como o Proto-evangelho de Tiago e o Evangelho do Pseudo-Mateus;

c) quem redigiu o texto tem notável conhecimento de tradições concernentes a Maria, quanto a símbolos a ela associados (palmeira, pedra), quanto à topografia de Jerusalém e cercanias a ela relacionadas (o lugar do parto), em relação a monumentos a ela dedicados ${ }^{10}$, a liturgias em comemoração dela, e ainda no que diz respeito a controvérsias em torno da legitimidade de seu parto;

\footnotetext{
${ }^{10}$ Penso numa igreja conhecida então como "Káthisma toû Theotókou", ou seja, "Assento da parturiente de Deus". Ela comportava em seu interior uma pedra em torno da qual corria um veio de água. E um dos mosaicos gravados em seu chão reproduzia uma frondosa palmeira ladeada de outras duas, menores. Tudo isso para marcar o lugar em que, segundo uma tradição que poderia estar ancorada no Proto-Evangelho de Tiago, teria ocorrido o nascimento de Jesus. As aproximações com o texto corânico são evidentes (Shoemaker 2003).
} 
d) a conjugação entre palmeira e curso d'água sugeriria também um conhecimento de narrativas, de matriz greco-romana, concernentes a nascimentos de deuses, eventualmente reelaboradas em ambientes cristãos;

e) no tocante especificamente à figura de Jesus, durante toda a sessão narrativa, o texto cuidadosamente se afasta de algumas de suas matrizes (diretas ou indiretas), como o Evangelho segundo Lucas e o Diatessaron: se de um lado acentua (na esteira do Proto-evangelho de Tiago) a concepção miraculosa por Maria e a legitimação do parto de Jesus (o que, obviamente, faz dele uma figura diferenciada), de outro apresenta este último apenas como "servo" e "profeta" de Deus, o que prepara a posição categórica, contrária a tomá-lo como seu "filho", situando-se, portanto, em meio a um emaranhado de afirmações e negações a respeito dessa delicada questão, que já vinha fazendo correrem tinta e sangue há uns bons séculos, como, aliás, o próprio texto reconhece (a.37); o próprio paralelo estabelecido entre João e Jesus, bastante estreito, não representa apenas uma elaborada construção literária, mas uma tomada de posição quanto aos então discutidos vínculos "espirituais" entre os dois personagens;

f) a expressão "irmã de Aarão", aplicada a Maria na a.28, mostra conhecimento de resultados daquilo que se costuma denominar "exegese tipológica";

g) a aproximação de algumas aleias (33-36) com inscrições sobre Jesus encontradas nas paredes do Domo da Rocha (em Jerusalém) instiga a pensar sobre as matrizes destes dizeres e a composição do fragmento ouvido.

Ou seja, o que nosso peregrino pôde escutar se constitui num todo resultante da convergência (entre tantas possíveis) entre diversas tradições, detalhes, narrativas, símbolos e memórias não necessariamente coincidentes em todos os detalhes. Seu enraizamento nos meandros nebulosos e multifacetados da antiguidade cristã médio-oriental é notável. Nele confluem trajetórias de textos vários, ecos de controvérsias seculares. São elas que interessam na argumentação que aqui construo.

\section{Da crença aos pressupostos acadêmicos}

Sendo o texto em questão, em sua unidade e originalidade, feito todo ele, praticamente, de material corrente, plenamente ancorado no mundo da Antiguidade tardia médio-oriental, eco de tantas vozes e escritos, concepções e práticas, memórias e tradições, mapear o universo em que eles poderão ter circulado e interagido se mostra um desafio. O problema, no entanto, se agiganta quando temos em conta que ele, o texto, se nos chega como componente destacado de um livro particular, o Corão, cuja origem em sua totalidade tem 
sido atribuída, de forma direta ou indireta, tanto pela tradição religiosa a ele vinculada, como por boa parte da pesquisa acadêmica dos últimos dois séculos, à vida e atividade de uma pessoa em particular, Muhammad, o profeta do islã. Um dos efeitos desta atribuição tem sido que os vínculos, que um texto como o que foi comentado evidencia, com um universo mais amplo e de trajetórias de longa duração acabam por ficar na penumbra. Mas o Corão como um todo e outros testemunhos literários do incipiente islã remetem inevitavelmente a um caleidoscópio sociocultural e religioso do Oriente Médio nos últimos séculos da Antiguidade, cuja complexidade ultrapassa enormemente o mais sofisticado quadro que se possa delinear. Não há como escapar de questões como as seguintes:

a) o caráter alusivo e conciso do relato corânico, que remete a um subtexto, conhecido do público para o qual inicialmente foi pensado, e dele dependente para sua compreensão, que já recebeu a qualificação de "bíblico"11; foi o desaparecimento do subtexto bíblico do horizonte dos receptores do livro sagrado muçulmano que lhes ofereceu um sem-número de novas possibilidades de entendimento, aspecto fundamental para a compreensão dos rastros que esse livro vai deixando nos diversos contextos e situações em que se vai inserindo;

b) este mundo "bíblico" exige a consideração dos grupos judeus, judeucristãos e cristãos (de variados tons e matizes) que conviviam e interagiam - também em situações conflitivas - no mundo da Antiguidade tardia médiooriental, um cenário abertamente "sectário";

c) mas se o objetivo é chegar a tais grupos que, ao início e ao cabo, constituem o caldo sociocultural no e do qual emerge o islã, o Corão é fonte privilegiada de acesso ao universo deles: precisa ser abordado de forma atenta e crítica. É preciso escapar a isso que já foi chamado "big-bang muhamádico" (González Ferrín 2015: 84) a respeito das origens do Corão e do islã. Um livro e uma comunidade, ambos tradicionalmente vistos como homogêneos, supostamente surgidos como verso e anverso, rápida e complementarmente configurados. Senão vejamos:

o conteúdo sagrado do Alcorão [...] compreende uma série de revelações dadas a Maomé entre 610 [de nosso calendário] e sua morte em 632. [...] Essas comunicações enviadas por Deus foram repetidas textual e publicamente por Maomé durante os 22 anos de seu ministério em Meca entre 610 e 622, e depois em Medina, de 622 a 632 [...]. Portanto o Alcorão é as palavras de Deus, repetidas, sem erro, por seu "enviado" ou "mensageiro" (rasul), como ele é

\footnotetext{
11 Reynolds 2010: por "bíblico" Reynolds entende as escrituras judaica e cristã, tomadas em sentido mais alargado, ou seja, incluídos nelas textos que hoje são denominados apócrifos, bem como outros de cunho exegético (por exemplo o Talmude, no caso judaico): “O Corão parece dirigir o leitor, por meio de alusões e referências, a certas tradições que oferecem a base para a apreciação de sua mensagem. O Corão desperta a memória da audiência quanto a estas tradições bíblicas e então procede sem pausa para desenvolver sua mensagem religiosa" (p. 2).
}

Araucaria. Revista Iberoamericana de Filosofia, Política, Humanidades y Relaciones Internacionales, año $21, \mathrm{n}^{\circ} 41$. Primer semestre de 2019. Pp. 369-393. ISSN 1575-6823 e-ISSN 2340-2199 doi: 10.12795/araucaria.2019.i41.18 
chamado no Alcorão, e como todo muçulmano deve crer (Peters 2008: 47; o destaque é meu).

Note-se a absoluta concordância entre o que aí se propõe como síntese sobre as origens do Corão, apresentada sem qualquer ressalva ou discussão prévia, e aquilo que, Peters mesmo reconhece, "todo muçulmano deve crer". Não há por que olhar atrás, antes ou além do livro:

alguns muçulmanos modernos reconhecem certamente um elemento humano na escritura, mas apenas a ponto de admitirem que ela contém referências históricas a acontecimentos da vida do Profeta. A vasta maioria, porém, considera que uma investigação às fontes do Qur'ān é pura descrença. Deus é o autor das histórias sobre o Faraó, como de toda a demais revelação escrita. O que Maomé possa ter já conhecido é irrelevante.

A força do dogma avança e se apossa da investigação, reduzindo-lhe e desviando-lhe o horizonte:

... a presença de tanto material bíblico no Alcorão levantou suspeita entre não muçulmanos de que desde o começo Maomé esteve em contato com judeus [e cristãos] que serviram, conscientemente ou não, como seus informantes. [...] A questão sobre se Maomé "tomou emprestado" alguma coisa desta parte para sua própria mensagem depende do grau de originalidade que se está disposto a atribuir aos profetas, ou, de modo mais pertinente, aos profetas de outros povos (Peters 2007: 124).

É que tem sido desenvolvido algo como um "paradigma nöldekiano" (Dye 2014: 2), associado à figura do importante estudioso do Corão Theodor Nöldeke (1836-1930), que reproduz e sofistica para a academia, em forma e conteúdo, aquilo em que "todo muçulmano deve crer". Senão vejamos: sua obra monumental Geschichte des Qorans, surgida inicialmente como tese de doutorado em 1860, com notáveis acréscimos e revisões, d ele mesmo e de discípulos, deixou estabelecidos dois postulados básicos: 1) o texto corânico que nos chegou é expressão da experiência de uma comunidade formada em torno do profeta Muhammad e que com ele viveu duas fases distintas e decisivas, primeiramente em Meca, depois em Medina; 2) é possível e necessário estabelecer a cronologia das proclamações orais do profeta através do exame das suras e de sua classificação básica em mecanas ou medinenses, encontrada no próprio livro. ${ }^{12}$ Nöldeke não teme afirmar que "o Corão contém apenas 
peças originais" (citado por Dye 2014: 2), ou seja, pronunciadas pelo profeta, não cabendo qualquer dúvida em relação a isso. Por outro lado, é só neste livro e por meio dele que se tem acesso à pregação do líder. O contexto do qual cada um dos conteúdos que haveriam de formar o livro veio à luz é oferecido pela indicação (mecana ou medinense) feita no início de praticamente todas as suras; tais conteúdos eram conhecidos dos companheiros de Muhammad e estavam virtualmente já redigidos quando da morte deste; talvez se encontrassem dispersos, recolhidos que estavam em materiais vários; a tarefa posterior foi exclusivamente a de recolher e dispor o material dando-lhe uma organização, o que ocorreu, de forma definitiva, sob o califado de Uthman (644-656), e o Corão que conhecemos hoje corresponde rigorosamente àquele estabelecido pelo califa. A edição difundida a partir dos tempos de 'Abd al-Malik (685-705) não é outra que aquela definida trinta anos antes. A força destes postulados é grande o suficiente que para que sejam relativizados testemunhos ou indícios que apontariam noutras direções, como fragmentos de antigos manuscritos e depoimentos encontrados no interior da própria tradição muçulmana dando conta de diversidades e controvérsias quanto a dizeres, conteúdos e formatos do texto.

Angelika Neuwirth é talvez a mais destacada e destemida pesquisadora na atualidade a sustentar, com vigor, a pertinência do "paradigma nöldekiano". Assumindo o "cenário tradicional da redação uthmaniana" como razoável, aposta na "hipótese de que os resquícios das recitações do Profeta foram coletados pouco depois de sua morte para formar o corpus que temos diante de nós"; a mais plausível, embora impossível de ser provada (Neuwirth 2003: 11). Sua ampla pesquisa "pressupõe a confiabilidade dos dados básicos dos relatos tradicionais sobre a emergência do Corão, assumindo o texto corânico transmitido como a coleção genuína das comunicações do Profeta tais como pronunciadas durante suas atividades" (Neuwirth 2007: 100; o destaque é meu). O que significa, ao final, que

uma leitura verdadeiramente contextual do Corão (oposta a uma mera leitura do contexto do Corão) não deve contentar-se em dissolvê-lo em suas fontes judaicas, cristãs ou de outra ordem, mas ao final permitir que ele possa revelarse como texto em si mesmo, isto é, um discurso - ou, antes, uma série de discursos diacronicamente contíguos - dotado de sua própria e peculiar agenda teológica e lógica literária (Sinai e Neuwirth 2010: 12-13; o destaque é dos autores).

como ilustrações da natureza e da história (em especial remetendo a narrativas de fundo bíblico) que apelam à confiança na onipotência e na bondade de Deus. As suras do terceiro período (620-622) são ainda mais longas, e soam, por vezes, repetitivas. Já aquelas dos tempos de Medina (622-632) estão orientadas para a consolidação da comunidade muçulmana e da atividade do Profeta como seu líder máximo (p. 108). Para a denúncia do caráter arbitrário desta cronologia, em particular no tocante à sura 19, veja Wansbrough 2004: 41. 
O que Neuwirth chama, depreciativamente, de "dissolver" o texto corânico em suas fontes e tradições é exatamente a operação que poderá lançar luzes sobre dinâmicas socioculturais em curso no ambiente que viu nascerem os textos que o formam e, mais ainda, do seio das quais eles provêm. É muito pouco constatar que a sura 19 tenha desempenhado importante papel na relação da primeva comunidade islâmica com segmentos cristãos, como postula a tradição (Nasr 2015: 763); na verdade temos aí um equívoco de base, o de se supor uma "comunidade islâmica" claramente identificada e definida na primeira metade do século VII. Assim como é pouquíssimo investigar uma sura como a 19 desconsiderando praticamente os caminhos pelos quais a presença do material de que ela se compõe veio a se tornar possível e relevante; eles demandam ser identificados e trilhados, não só para que se evidenciem com mais clareza os propósitos de quem deu a configuração "final" ao texto, pela qual ele veio a ser conhecido e a chegar a nós - afinal de contas a sua redação estava marcada pelas demandas do tempo em que ela estava ocorrendo, e os materiais utilizados carregavam aquelas do de sua confecção e dos de sua transmissão - como também para que se iluminem nervuras estruturais, eventualmente subterrâneas, mas nem por isso menos relevantes, das dinâmicas sociais, históricas e religiosas que viabilizaram o islã nascente e seu livro.

\section{Quebrando o consenso: da formação do Corão ao islã dos primórdios}

A despeito desta convergência entre a crença islâmica e as linhas mestras do "paradigma nöldekiano" quanto ao entendimento das origens do Corão - ou, para ser mais exato, a despeito desta subordinação da pesquisa sobre as origens do islã e do Corão aos limites estabelecidos pelo mito muçulmano a respeito delas - é forçosa a constatação: o texto hoje reconhecido como único, expressão exata dos ditos do Profeta, que se toma por organizado e redigido em tempo espantosamente rápido, efetivamente "demorou muitos séculos para ser aceito por todos os muçulmanos como textus receptus". Foi um tempo de múltiplas discussões e polêmicas, que se confundem com os tempos e questões de que se alimenta o islã dos primórdios: "a 'ortodoxia' posterior, por razões ideológicas evidentes, passará em silêncio estas controvérsias fecundas que vêm hoje ilustrar uma pluralidade insuspeita de pontos de vista" (Amir-Moezzi e Kohlberg 2007: 191.178).

Para uma visão panorâmica destas controvérsias, que não são de hoje, vale considerar que um tal consenso a respeito das origens do Corão, mesmo no universo da crença e da teologia muçulmanas, nunca existiu. A adesão a ele - o consenso - só pode ser feita à custa da ignorância de elementos encontrados nas próprias tradições muçulmanas, que podem ser resumidos nos seguintes pontos (sigo Prémare 2015: 9-10): 
a) nos territórios alcançados pela chamada "conquista árabe" começaram a aparecer diversas coleções de materiais que denominaríamos "corânicos", situação em relação à qual o empreendimento já mencionado de Uthman teria buscado estabelecer (e mesmo impor) um consenso; tentativa semelhante seria levada a cabo pelo primeiro califa omíada de Damasco, Mu'âwiya, atuante entre os anos 660-680;

b) o califa 'Abd al-Malik terá assumido, na virada do século VII para o VIII, publicar uma edição revista a partir de versões que estavam em circulação; esta versão teria chegado ao conhecimento dos primeiros apologistas cristãos que se dedicaram a contestar passagens do Corão; mas - pergunto eu - se assim foi, por que João Damasceno, atuante na primeira metade do século VIII, não faz qualquer alusão a um Corão já acabado?

c) mais para o fim do século VIII outro califa estabeleceu um códex corânico que deveria substituir os anteriores;

d) debates sobre os textos avançam até o século $X$, em vistas a definir as variantes de leitura autorizadas no ensino e nas práticas cultuais;

e) o Corão só veio aparecer como livro impresso no fim do século XVIII. E a versão egípcia dele, surgida no Cairo em 1923, se tornou padrão e referência no mundo todo. O importante a ser notado é que ela foi preparada tendo como base uma das "sete leituras" tradicionais (derivadas de os textos, nesses tempos, não portarem sinais diacríticos), feita autoridade, aquela de Kûfa (cidade situada no atual Iraque).

E uma série significativa de estudos sobre a formação do Corão tem alargado o horizonte de perspectivas, em duas direções: a) considerar o ambiente mais amplo (o contexto do Oriente Médio no período da Antiguidade tardia) como pano-de-fundo indispensável para o entendimento dos conteúdos presentes no livro; b) pensar que a redação dos textos que vão formar os Corões ( $\operatorname{sim}$, as várias versões primevas dele) há de ser concebida num período de tempo mais amplo do que aquele aceito normalmente, tendo sofrido o impacto das vicissitudes experimentadas pelos grupos cujas trajetórias confluirão na configuração do islã dos primórdios. Talvez se possam tomar aqui, como emblemáticas, duas figuras que ilustram essas duas vertentes da pesquisa mais crítica a respeito da formação do Corão no bojo do surgimento do islã, em temporalidade e ambiente mais largos e complexos.

Christoph Luxenberg é na verdade o pseudônimo de um intelectual cuja identidade não é conhecida, alguém que, na esteira de estudos anteriores, trabalhando particularmente em perspectiva filológica, insere o Corão num pano-de-fundo de fala e escrita siríaca (predominantes no Oriente Médio nos tempos da Antiguidade tardia), o que remete a um contexto marcada e pluralmente cristão. Segundo ele, o Corão se desenvolveu a partir da Qeryana, um tipo de devocionário do cristianismo siríaco. Partes importantes do que hoje 
é o Corão foram escritas nesta língua, e quando lidas num ambiente de fala árabe muitas passagens acabaram ganhando novos sentidos, ou mesmo se tornaram de difícil compreensão. E a interpretação que o texto corânico foi ganhando no desenrolar da história islâmica considerou-o a partir do estabelecimento do texto em árabe, sem considerar esse processo prévio. Daí que Luxenberg proponha algo como uma retrotradução, entendendo que a recuperação do panode-fundo original, qual seja, o ambiente de fala e escrita siríaca, é fundamental para o entendimento de tantas passagens do atual Corão. O caso da a.24 da sura 19 é emblemático: em vez do tradicional "Não te atormentes, porque fez correr teu Senhor debaixo de ti um regato", Luxenberg propõe que leiamos, como conteúdo da palavra que uma voz dirige a Maria, nada menos que "Não te entristeças! Teu Senhor tornou legítimo o teu parto" (2007: 127-142). E, efetivamente, o que o estudioso encontra como resultado é que, em vários momentos, fica-se muito (mais) próximo de textos da tradição cristã siríaca. Cabe, portanto, a necessidade de pensar o Corão, em termos de sua formação, retrocedendo quanto aos supostos tempos de Muhammad e situando-o como um produto da Antiguidade tardia cristã (siríaca) médio-oriental.

Assim, por este caminho filológico Luxenberg alarga principalmente para trás, para antes dos anos supostos para a vida do Profeta, o tempo dentro do qual deve ser pensado o processo de gestação do Corão. Mas John Wansbrough, em fins dos anos 1970, propusera ampliá-lo também para frente. Em suas obras $(2004 ; 2006)$ combinam-se análise dos diferentes aspectos teológicoreligiosos próprios ao texto corânico, a história de sua composição e exegese, o estudo do meio religioso que terá proporcionado aos primeiros muçulmanos o embasamento conceptual e as ferramentas interpretativas fundamentais, e o exame de como tudo isso terá confluído na escrita de uma história da salvação, finalizada apenas em inícios do século IX. É que o estudioso estadunidense tratou de aplicar ao Corão, bem como aos primeiros testemunhos escritos no mundo do islã, o conjunto de procedimentos utilizado nos estudos bíblicos denominado "método histórico-crítico". Atento a tendências teológicas distintas detectáveis nos textos, ocupa-se do ambiente que ofereceu aos protomuçulmanos os conceitos e os modelos interpretativos das tradições que fundavam seu itinerário religioso, concluindo que a elaboração do Corão acompanhou pelo menos o primeiro século e meio de trajetórias, distintas nas formas, crenças e práticas, de grupos afins mas diversos, que só ao final de mais cinquenta anos teriam definido, em suas grandes linhas, seu mito de origem e os princípios de sua presença enquanto identidade específica; grosso modo, está-se falando aí de um processo que abrange os séculos VII e VIII, ingressando no seguinte. Não há que pensá-lo - o mito - prévio ou alheio ao desenvolvimento histórico de comunidades e da literatura mais ampla produzida no interior delas; pelo contrário, sua configuração acompanhou e repercutiu as vicissitudes vividas 
pelos diversos grupos que confluiriam naquilo que hoje chamamos islã. Tanto o Corão como os demais escritos surgidos neste ambiente devem ser avaliados à luz de seus respectivos gêneros literários e com a devida consideração a este específico e dinâmico Sitz im leben.

Em outras palavras, Wansbrough propõe para a abordagem dos primórdios do islã uma inversão de perspectiva similar àquela que, há mais de oitenta anos, Walter Bauer estabeleceu para a análise histórica do cristianismo dos primeiros séculos: no princípio do movimento não era a unidade, em torno da figura do Profeta, sua mensagem e indicações, a partir da qual teriam sido desencadeadas as chamadas "conquistas árabes", ou de dentro da qual teriam surgido os desvios; pelo contrário, foi de variados tons de judaísmos e cristianismos, com suas diferenças, competições e rivalidades que, nas inevitáveis tensões e conflitos próprias de dinâmicas sociorreligiosas em ebulição e emergência, emergiu o islã que identificamos como tal. Assim, mais importante que a suposta Arábia dos tempos de Muhammad é o que Wansbrough denomina "ambiente sectário" do Oriente Médio mais amplo. As raízes do islã estão em argumentos, polêmicas e práticas que permeavam grupos monoteístas situados à margem das tradições religiosas majoritárias existentes no Oriente Médio, ao mesmo tempo em que as permeavam. Entre eles se ressaltam os que, na falta de melhor nome, costumam ser identificados como "judeu-cristãos" (logo trataremos deles). O futuro islã vai emergindo de dentro destes grupos sectários em interação, hibridização e diferenciação. O Corão resulta de seleções dos materiais que circulavam entre eles, devidamente articuladas em processos redacionais que demoraram a estabelecer uma unidade textual geral. E o islã procederá a uma interpretação retrospectiva de suas origens nos termos de um mito centrado na figura do Profeta em sua missão em Meca e Medina, o que resultou num efetivo paradoxo: é menos difícil traçar a história da confecção do mito que aquela dos processos que gestaram o islã e dentro dos quais tal mito foi confeccionado.

Assimfica posto, de forma definitiva einescapável, o desafio de compreender o islã dos primórdios e o Corão no âmbito de um ambiente mais alargado, como expressões da Antiguidade tardia médio-oriental, em seu complexo político, cultural, socioeconômico, religioso. Não são eventuais influências e contatos vividos por Muhammad que explicam o amplo e profundo enraizamento dos textos do Corão e do nascente islã no mundo social e cultural que o viu nascer: os próprios testemunhos escritos primordiais sobre a vida do profeta também bebem do mesmo caldo cultural e se situam no âmbito da literatura que ancora a gestação e configuração de uma nova identidade religiosa. Assim, na esteira destes instigantes estudos, entre outros, é possível concluir:

[...] o Corão não foi - como argumenta a mitologia beduinizante e genesíaca

- a resposta tardia ao politeísmo primitivo da chamada Arábia pre-islâmica; 
foi decantação final, resposta revelada ao aberto e ampliado mundo de ideias religiosas e enfrentamentos políticos neste Oriente Próximo de judeucristianismos, concílios, perseguições, debates bizantinos [...] (González Ferrín 2018: 334; o destaque é do autor).

E, mais adiante:

[...] o islã não é uma cisão; mas se produziu um questionamento de invólucros sistemáticos para, de todo o totum revolutum, dar passagem a três novas formas de ortodoxia diferenciadas. Os mesmos materiais que davam forma a duas ortodoxias - cristianismo oficial e judaísmo rabínico - assim como todas as suas zonas ideológicas intermediárias, se reorganizaram, se embaralharam novamente, e se desenhou de novo o espectro completo em torno de três sistemas (p. 362; destaques do autor).

E o Corão é a expressão literária decantada dos resultados a que este novo embaralhar dos materiais, gerador do islã, conduziu. É hora de verificar alguns traços deste universo embaralhado em que e do qual ambos, o primeiro islã e o Corão, emergem.

\section{Judeu-cristianismos no "ambiente sectário" da matriz do Corão e do islã}

A despeito da enorme dificuldade implicada na tarefa de imaginar o que possam ter sido os movimentos, os passos e os processos que, ao final, fizeram emergir o islã das entranhas do mundo médio-oriental dos tempos tardoantigos, a tarefa se impõe, a partir de pressupostos como os que indico a seguir, sem a pretensão de ser exaustivo:

a) dar ao mito de origem que no seio do islamismo foi concebido a respeito de si mesmo o reconhecimento do seu lugar e relevância no estrito e específico âmbito do que ele pretende ser, a saber, um mito;

b) aplicar aos testemunhos literários surgidos no nascente islã - incluído o Corão - os procedimentos "histórico-críticos"tornados clássicos nos estudos bíblicos acadêmicos, assumindo tanto as pertinentes críticas endereçadas a alguns de seus pressupostos filosóficos e metodológicos quanto os desdobramentos e avanços em vários âmbitos das chamadas Ciências Humanas; isto implica, entre outras coisas, identificar e enfrentar em perspectiva historiográfica a dinâmica das tradições que embasam os textos corânicos, como apontei rapidamente no tocante à sura 19 ;

c) recuperar o que a investigação tem identificado quanto àqueles tempos $\mathrm{e}$ espaços do mundo médio-oriental entre os anos 400-800; a Antiguidade tardia que, por estar entre aqueles dois tempos convencionalmente distinguidos na 
trajetória histórica, costuma ser olhada com menos atenção: ou apenas fim/ decadência da era antiga, ou mero intróito para o Medievo;

d) nesse ambiente complexo e cheio de muitas informações e fontes à espera de serem interpretadas e articuladas, uma atenção ao universo sociorreligioso plural e multifacetado, cheio de meandros, tons e colorações, intercâmbios e conflitos se faz indispensável.

Os limites deste artigo não permitem mais do que algumas indicações derivadas dos pressupostos acima apresentados, o que proporei nas linhas seguintes, afunilando-me em um ponto sobre o qual me deterei um pouco mais.

\title{
4.1. Dinâmicas sóciorreligiosas, entre diversidades e turbulências
}

Comentando o brutal assassinato da filósofa alexandrina Hipátia, nos inícios do século V, Avril Cameron (1998: p.23-24) assim se expressa:

\begin{abstract}
É indubitável que Alexandria era propensa a sofrer estalidos de violência como estes [ela se refere ao incêndio, provocado por monges, de um templo dedicado ao deus egípcio Serápis], mas o certo é que em cada cidade se dava uma peculiar mescla de religiões, de sorte que, atiçados pelo fanatismo de alguns monges e de determinados cabecilhas religiosos, os distúrbios foram tornando-se cada vez mais frequentes durante os séculos Ve VI, na medida em que se foi incrementando a população urbana em muitas das cidades do Oriente (o destaque é meu).
\end{abstract}

São tempos em que multidões anônimas lincham bispos e decapitam clérigos, grupos cristãos disputam favores imperiais e a consequente repressão aos adversários (sejam eles cristãos, judeus, pagãos), monges e bispos lideram milícias: guerras por Jesus e em seu nome, apropriações imperiais de seu nome, alimentadas de acesas querelas teológicas... Distúrbios desta ordem, se existiam antes, avançaram pelo século VII adentro e ainda mais, junto a outros: sublevações de toda ordem, pilhagens, emigrações, contingentes armados avançando para lá e cá. São tempos nada monótonos,

[...] de impérios que se desgastam e fragmentam, desertos povoados de gerações de monacato fugidio, massivo, insubmisso [...], substrato ideológico de mil e um judeu-cristianismos e maniqueísmos, fertilizante semítico plasmado, por sua vez, em língua siríaca [...] (González Ferrín 2018: 312).

Com efeito, as três primeiras décadas do século VII de nossa era viram as guerras entre persas (sassânidas) e romanos (bizantinos) sacudindo o Oriente Médio, sem que uma potência lograsse impor-se efetivamente à outra. Neste cenário, em não poucos segmentos (judeus, cristãos, zoroastristas) se aprofundou um acentuado fervor apocalíptico, de que é testemunha uma significativa 
literatura: as batalhas travadas pelas forças imperialistas pressagiavam o fim do mundo. Para alguns a restauração do templo de Jerusalém era condição necessária para o tão ansiado como temido juízo final. As chamadas "conquistas árabes" - da Palestina, do Egito, da Síria e do Iraque - de meados do século hão de ser lidas neste contexto de guerras entre impérios - e reações a eles - e acesas expectativas estatologico-apocalípticas.

\subsection{Judeus, cristãos, judeu-cristãos}

Neste cenário assim dinâmico e turbulento há que se pensar a formação do Corão e as origens do islã. E já que se falou de literatura, cabe recolher esta sutil observação:

ler o Corão à luz da literatura tardo-antiga [...] é significativo apenas se fica claro que o que é relevante são textos tardo-antigos judeus ou cristãos. [...] a cultura tardo-antiga no Oriente Próximo ofereceu uma rica gama de possibilidades exegéticas. Todas as tendências sectárias e hermenêuticas decorrentes dos textos fundacionais de judeus e cristãos devem então ser estudadas juntas. Estes incluem não apenas os vários grupos judeu-cristãos mencionados pelos heresiólogos cristãos, como os ebionitas, os nazarenos ou os elkasaítas, mas também os dualistas gnósticos e maniqueus, e ainda as "nobres" heresias do monofisismo e do nestorianismo, que juntos representam a maioria dos cristãos tardo-antigos no Oriente Próximo, do Egito e Síria à Armênia e Irã (Stroumsa 2015: 80).

Em relação a tais "nobres" correntes, valha a seguinte passagem, atribuída a um dos sábios dos primórdios da tradição muçulmana, Ibn Kathir: depois que Jesus foi elevado ao céu,

eles [os cristãos] se dividiram em três grupos. Um deles, Al-Ya'qubiyyah [os jacobitas, uma expressão do monofisismo], disse: "Allah permaneceu conosco o quanto quis e então subiu aos céus". Outro grupo, An-Nasturiyyah [os nestorianos], disse: "o Filho de Allah permaneceu conosco o quanto Deus quis, e então Ele o elevou ao céu". Um terceiro grupo disse: "o servo e mensageiro de Deus esteve entre nós o quanto Deus quis, e então Ele o elevou para junto dele. O último grupo é o muçulmano. Os dois grupos descrentes colaboraram contra o grupo muçulmano e o aniquilaram. O islã ficou injustamente escondido até quando Allah enviou Muhammad (citado por Akyol 2017: 252, n.52).

Interessante notar como na explanação acima seu autor posiciona o grupo muçulmano entre segmentos cristãos marcantes emergindo do meio deles sob tensões e divergências. No entanto, é preciso acrescentar uma outra observação: estamos num mundo em que é muitas vezes difícil distinguir 
um herege judeu-cristão de um protomuçulmano ou um partidário de Ario ou Nestório, ou ainda maniqueu, ou por acaso alguém influenciado pelos ensinamentos de Simão, o mago, ou recorrente leitor dos escritos de Marcião, ou batista pré-cristão, ou tantas outras possibilidades de interpretar o mundo por meio de comportamentos pessoais de seguimento coletivo, incompatíveis só posteriormente (Ferrín 2018: 159).

Se em alguns lugares e ocasiões se estabeleceram verdadeiras facções separando nicenos de arianos, nestorianos de monofisitas, em tantas outras oportunidades a convivência era o mais comum; debates, controvérsias e atos de violência costumavam ganhar vida quanto mais eram altos os degraus das hierarquias políticas, sociais e eclesiásticas ocupados pelos envolvidos:

no cotidiano as fronteiras não estavam tão definidas como na teoria do Estado e dos intelectuais, pois as experiências se caracterizaram por sua riqueza e variedade. [...] para além das diferenças que possam existir entre os credos religiosos, há algo que seus seguidores têm em comum, que são seus sentimentos, preocupações, anseios, medos, as necessidades básicas a serem supridas na vida, tanto materiais como emocionais, e isto é algo que transcende as diferenças e muitas vezes une e integra as pessoas (Ubric Rabaneda 2007: 164).

Assim, estamos no mundo dos "cristianismos em siríaco", "em ebulição sociológica e soteriológica", "caracterizado por um permanente e aceso debate entre correntes" dentro do qual se delineava uma "ortodoxia nicena e calcedoniana [...] avançando para posterior consolidação" e "contra a qual emergirá uma enorme periferia cristalizada depois na síntese islâmica" (Ferrín 2018: 245). O que interessa aqui é tal periferia antes da referida síntese, na qual se encontram, difíceis de serem identificadas com mais nitidez, as raízes do primeiro islã e as matrizes do Corão: é preciso percorrer também e principalmente os pequenos fluxos, recolher indícios fugidios, contatar gente anônima e desconhecida. Ou seja, o cenário é mais complexo: no interior dele há o extensíssimo e obscuro universo dos judeu-cristianismos feito de tantas cores e tons, para além dos grupos e facetas que as catilinárias dos heresiarcas lograram identificar. Os elos que o mostram vinculado ao islã nascente e ao texto corânico estão longe de ser identificados e interpretados de maneira suficiente; por isso neles me concentro, certamente considerando que

não podemos identificar uma fonte como única origem dos conceitos e fórmulas do Corão excluindo outras filiações possíveis. Ao mesmo tempo o princípio de não-exclusividade é também princípio de indeterminação: num mundo onde ideias religiosas estão em circulação permanente e em transformação contínua, parece praticamente impossível determinar a proveniência precisa destas ideias ou os canais próximos pelos quais elas tais como alcançaram o Corão (Stroumsa 2015: 82). 
Os grupos judeu-cristãos começaram a emergir e aparecer à investigação na medida em que as fontes que a eles se referem começaram a ser lidas de modo mais acurado e crítico, desafiando a narrativa tradicional sobre uma suposta e antiga separação entre judaísmo e cristianismo (associada a um mítico "concílio de Jâmnia", dos tempos imediatamente posteriores à destruição de Jerusalém pelo imperialismo romano, no ano 70 de nossa era), em favor do entendimento de um processo muito diversificado e estendido por longos séculos, que ao final são os tempos do alvorecer do islã (Fonrobert 2010: 234-235).

No sentido estrito que esta expressão altamente problemática costuma assumir, "judeu-cristianismo" designa "um desenvolvimento muito especial na formação de congregações de seguidores de Jesus que interpretavam a lei de Moisés de um modo que não era seguido pela maioria dos cristãos gentios". Típico para estes grupos, variados e dispersos, era "o compromisso com a observância ritual da lei de Moisés, inclusive a circuncisão e as leis relacionadas com a pureza e a alimentação" (Koester 2005: 217). Por outro lado, é preciso não perder de vista aquilo que, de forma perspicaz, é anotado por Segovia (2010: 95) de maneira incisiva: o judeu-cristianismo sectário de que aqui se trata, ou seja, aquele manifestado em grupo(s) específico(s), cujos contornos é muito difícil caracterizar, se distingue (sem necessariamente se se separar, muito menos se opor) da "realidade de um cristianismo que pode e deve, legitimamente, ser qualificado como judeu-cristão, qual seja: o cristianismo palestinense e assírio ao menos até o século V" (os destaques são do autor). Grupos representativos deste "judeu-cristianismo sectário"

não parecem ter desaparecido da cena da Antiguidade tardia. As fontes (ou ao menos as confiáveis) são bastante escassas, e difíceis de serem interpretadas. [...] comunidades judeu-cristãs devem ter sido grupos pequenos, marginais, sempre vivendo em um isolamento protetor. Até onde eu conheço, não há prova clara e irrefutável de sua existência no século VII. Mas os traços que eles deixaram constituem evidência circunstancial suficiente para nos permitir a proposição de sua continuada existência para tempos bem posteriores ao século IV (quando Epifânio e Jerônimo atestam inegavelmente sua presença) e seu Fortleben [continuidade]. [...] A efetiva existência destes grupos, no entanto, é menos surpreendente que o impacto que eles podem ter tido, para além de suas próprias fronteiras (Stroumsa 2015: 75). ${ }^{13}$

Já Guillaume Dye (2018: 26), cético quanto à possibilidade de se identificarem tais grupos nos tempos da emergência do islã, reconhece a presença, no Corão, do que denomina "sensibilidade judeu-cristã", para além dos limites que eles pudessem estabelecer. ${ }^{14}$ Assim, não importa que os grupos

${ }^{13}$ Nevo e Koren (2003: 192-195) apontam para presenças de judeu-cristãos em fins do século VII em Jerusalém, no norte da Mesopotâmia, entre outras regiões do Oriente Médio.

14 No mesmo parágrafo Dye pontua outros elementos presentes no Corão que exigem pensar 
supostos por Stroumsa não fossem "mais que umas poucas comunidades marginais"; aquele(s) dentro do(s) qual(is) era forjado o Corão seria(m) mais um(ns) deles. Mais significativo é que as ideias por eles esposadas, inaceitáveis tanto por rabinos como por bispos, tenham soado "como uma versão surpreendentemente atrativa do cristianismo, ao menos para pessoas que viviam nas margens do império bizantino" (Stroumsa 2015: 90). Cabe, portanto, falar de judeu-cristianismo para além das fronteiras dos grupos que com muito custo podem ser identificados, de uma "sensibilidade" que, claramente detectável no Corão, permeava tempos e ambientes dos quais ele nasceu e o islã emergiu. Assim sendo, por que não tomar o Corão (ou ao menos grande parte dele) como uma expressão a mais dos judeu-cristianismos? É porque este reconhecimento tende a causar horror que as expressões mais arrojadas da investigação ainda precisam manejar formulações que - aparentemente - operam como se estas duas grandezas (judeu-cristianismo e Corão) fossem grandezas distintas a serem então correlacionadas:

o Corão contém material de fontes variadas. Algo dele é material árabe nativo, como o acento no "fato conhecido" universalmente de que os árabes descendem de Abraão [...]. Algo foi emprestado de outras religiões monoteístas: judaísmo, cristianismo e especialmente judeu-cristianismo. O Corão alude repetidamente aos conteúdos do Pentateuco e dos evangelhos. Mas, embora seja verdade que a maioria do material corânico possa ser classificada como "judaica" ou "cristã" mais do que especificamente "judeu-cristã", por outro lado a influência desta última é central: enquanto o material "judeu" e "cristão" consiste de referências a "fatos conhecidos", ou de alusões a, e eventuais releituras de, histórias e lendas, o material judeu-cristão modelou a teologia do Corão (Nevo e Koren 2003: 337-338; o destaque é dos autores).

Afinal de contas, como entender que os tópicos que seguem abaixo, na síntese proposta pelos mesmos autores, se são tipicamente judeu-cristãos, não são menos corânicos, proto-islâmicos (com alguma variação aqui e ali)? Ei-los:

a) "a crença de que Jesus não é o filho de Deus ou parte da divindade, mas um profeta a ele subordinado";

b) a polarização "conhecimento" x "ignorância" para definir a pertença à comunidade: “membros não são 'crentes' (como no cristianismo paulino) ou 'praticantes' (como no judaísmo rabínico), mas ‘homens de conhecimento', e o acesso à membresia da comunidade se dá pelo ser ensinado";

c) "a ênfase em Abraão como o primeiro "homem de conhecimento", de quem os judeu-cristãos se entendiam descendentes;

para ele um contexto que ultrapassa os judeu-cristianismos estritos, sejam grupos eventualmente existentes, seja a própria "sensibilidade" a que ele acabou de referir-se, o que corrobora o alerta de Stroumsa quanto ao já mencionado "princípio da não-exclusividade”. 
d) a direção assumida nos momentos das orações: a face voltada para Jerusalém;

e) negação da crucificação de Jesus;

f) a estima pela língua original da revelação divina comunicada a seus mensageiros, os profetas; no caso, o hebraico;

g) a convicção de que "o cristianismo paulino (especificamente o próprio Paulo) corrompeu a mensagem vinda de Deus por intermédio de Jesus";

h) "insistência na observância da lei mosaica, da circuncisão e do sábado";

i) "aceitação dos profetas encontrados no Pentateuco - apenas eles especialmente Moisés e, é claro, Abraão, e também Noé e Ló", posição esta que aproximaria seus cultores do samaritanismo (Nevo e Koren 2003: 193-194; o destaque numa das citações é dos autores).

Da periferia das ortodoxias, insinuando-se em meio a elas, subvertendolhes tradições, um novo sistema religioso ganhava corpo e formas nos tempos do imaginado peregrino que, na virada do século VII para o seguinte, tomava contato com um dos textos escritos por ela assumidos, eventualmente reformulados.

\section{Conclusão}

O texto da sura 19, tanto em sua sessão narrativa (até a a.33) como naquela polêmica (a.34-40) evidencia o seu enraizamento num mundo em que ideias, escritos, memórias circulavam, e tendências se evidenciavam, embora não fossem ainda "definíveis claramente como estritamente cristãs, judaicas, maniqueias ou protomuçulmanas, simplesmente porque tais categorias atuais não corresponderiam a tudo o que podia constituir o etéreo e multiforme mundo monoteísta próximo-oriental" (Ferrín 2018: 247) de tempos como os dos séculos finais da Antiguidade no Oriente Médio, turbulentos, em que "monges, dissidentes, missionários, soldados, refugiados e mercadores, inter alia, todos favoreceram a livre circulação de ideias religiosas" (Stroumsa 2015: 79). Os textos que haveriam de constituir o Corão emergem daí: não apenas respiram os ares do ambiente que os viu nascer e para eles contribui, mas o propósito que presidiu sua compilação era o de marcar uma posição em meio a tantas outras, entre convergências e dissensões, sobre temas relevantes - entre os quais o referente ao perfil de Jesus - no entendimento que o(s) grupo(s) cuja(s) trajetória(s) confluiria(m) no islã dos primórdios ia $(\mathrm{m})$ constituindo de si mesmo(s).

Isto posto, cabe à academia devolver ao ambiente do qual derivou e dentro do qual vem fazendo sentido o entendimento convencional sobre a formação do Corão e as origens do islã deverá ser devolvido: o da comunidade religiosa com seu mito de origem. 


\section{Referências bibliográficas:}

Amir-Moezzi e Kohlberg 2007: M. A. Amir-Moezzi e E. Kohlberg, "Revelation et falsification. Introduction à l'édition du Kitab Al-Qira'at D'Al-Sayyari”. In: D. Delmaire et G. Gobillot (ed.) Exégèse et critique des textes sacrés: Judaïsme, Christianisme et Islam hier et aujourd'hui (Geuthner, 2007), p. 177-208.

Akyol 2017: M. Akyol, The Islamic Jesus: how the King of the Jews became a Prophet of the Muslims (St. Martin's, 2017).

Cameron 1998: A. Cameron, El mundo mediterráneo en la Antigüedad tardía (Crítica, 1998).

Dye 2012: G. Dye, “Lieux saints comuns, partagés ou confisqués: aux sources de quelques péricopes coraniques (Q 19:16-33)”. In: I. Dépret et G. Dye (ed.), Partage du sacré: transferts, devotions mixtes, rivalités interconfessionnelles (Modulaires Européennes, 2012), p. 55-122.

Dye 2014: G. Dye, "Su alcuni miti negli studi coranici" (Conferência na Università di Stranieri di Siena, 2014). In: https://academia,edu/6798469/ Su_alcuni_miti_negli_studi_coranici (23/09/15), $16 \mathrm{p}$.

Dye 2018: G. Dye. “Jewish Christianity, the Qur'ān, and Early Islam: some methodological caveats". In: F. R. Sánchez (ed), Jewish Christianity and the Origins of Islam (Brepols, 2018), p. 11-29.

Fonrobert 2010: C. E. Fonrobert, "Jewish Christians, Judaizers, and Christian Anti-Judaism”. In: V. Burrus (ed.), Late Ancient Christianity (Fortress, 2010), p. 234-254.

Geissinger 2009: A. Geissinger, “Mary in the Qur'an: Rereading Subversive

Births". In: R. S. Sabbath (ed.), Sacred Tropes: Tanakh, New Testament, and Qur'ān as Literature and Culture (Brill, 2009), p.379-392.

González Ferrín 2015: E. González Ferrín, “La encrucijada del Islam (y de la Islamología)". In: Erebea (Huelva, 2015), n.5, p. 71-88.

González Ferrín 2018: E. González Ferrín, A angústia de Abraão: as origens culturais do judaísmo, do cristianismo e do islamismo (Paulus, 2018).

Koester 2005: H. Koester, Introdução ao Novo Testamento (Paulus, 2005), t.2. Küng 2010: H. Küng, Islão: presente, passado e futuro (Edições 70, 2010).

Luxenberg 2007: C. Luxenberg, The Syro-Aramaic Reading of the Koran: a Contribution to the Decoding of the Language of the Koran (Verlag Hans Schiler, 2007).

Nasr 2015: S. H. Nasr (ed.), The Study Quran: a New Translation and Commentary (HarperOne, 2015).

Neuwirth 2003: A. Neuwirth, 'Qur'ān and History - A Disputed Relationship: Some Reflections on Qur'anic History and History in the Qur'ān”. In: Journal of Qur'anic Studies (Edinburgh, 2003), v.5, n.1, p. 1-18. 
Neuwirth 2007: A. Neuwirth. "Structural, linguistic and literary features". In: J.

D. McAuliffe (ed.), The Cambridge Companion to the Qur'ān (Cambridge University, 2007), p. 97-113.

Nevo e Koren 2003: Y. Nevo and J. Koren, Crossroads to Islam: the Origins of the Arab Religion and the Arab State (Prometheus Books, 2003).

Peters 2007: F. E. Peters, Os monoteístas: judeus, cristãos e muçulmanos v.I (Contexto, 2007).

Peters 2008: F. E. Peters, Os monoteístas: judeus, cristãos e muçulmanos v.II (Contexto, 2008).

Prémare 2015: A.-L. de Prémare, Aux origines du Coran: questions d'hier, approches d'aujourd'hui (Téraèdre, 2015).

Reynolds 2010: G. S. Reynolds, The Qur'ān and its Biblical Subtext (Routledge, 2010).

Robinson 2003: N. Robinson, Discovering the Qur'ān: a Contemporary Approach to a Veiled Text (SCM, 2003).

Segovia 2010: C. A. Segovia, "El judeocristianismo: uma nueva hipótesis; seguido de um resumen de la Demostración 17 de Afraates (sobre la divinidad de Cristo)". In: Isidorianum (Sevilla, 2010), n.27, p. 83-108.

Shoemaker 2003: S. Shoemaker, 'Christmas in the Qur'ān: the Qur'anic Account of Jesus' Nativity and Palestinian Local Tradition". In: Jerusalem Studies in Arabic and Islam (Jerusalém, 2003), n.28, p. 11-29.

Sinai e Neuwirth 2010: N. Sinai e A. Neuwirth. "Introduction". In: A. Neuwirth, N. Sinai e M. Marx (ed.), The Qur'ān in context. Historical and Literacy Investigations into the Qur'änic Milieu. Brill, 2010, p. 1-24.

Sivers 2003: P. von Sivers, "The Islamic Origins Debate Goes Public". In: History Compass (2003), n. 1, p. 1-16.

Stroumsa 2015: G. G. Stroumsa, "Jewish Christianity and Islamic Origins". In: Behnam Sadeghi, Asad Q. Ahmed, Adam Silverstein and Robert Hoyland (ed.), Islamic Cultures, Islamic Contexts: Essays in Honor of Profesor Patricia Crone (Brill, 2015), p. 72-96.

Toorawa 2011: S. M. Toorawa, "Sūrat Maryam (Q. 19): Lexicon, Lexical Echoes, English Translation". In: Journal of Qur'anic Studies (Edinburgh, 2011), v.13/1, p. 25-78.

Ubric Rabaneda 2007: P. Ubric Rabaneda, "La coexistencia religiosa en la cotidianeidad de la Antigüedad tardía". In: 'Ilu. Revista de Ciencias de las Religiones (Madrid, 2007). n.18, p. 145-165.

Wansbrough 2004: J. Wansbrough, Quranic Studies: Sources and Methods of Interpretation (Prometheus, 2004).

Wansbrough 2006: J. Wansbrough, The Sectarian Milieu: Content and Composition of Islamic Salvation History (Prometheus, 2006). 
